\title{
OPINI AUDIT, FINANCIAL DISTRESS, PERTUMBUHAN PERUSAHAAN KLIEN DAN PERGANTIAN MANAJEMEN TERHADAP AUDITOR SWITCHING
}

\author{
Mazda Eko Sri Tjahjono \\ Universitas Sultan Ageng Tirtayasa \\ mazda_tjahjono@yahoo.com \\ Saskia Khairunissa \\ Universitas Sultan Ageng Tirtayasa \\ Saskiakhairunnisa@gmail.com
}

\begin{abstract}
abstrak
Isu mengenai independensi auditor menjadi isu utama yang muncul akibat dari lamanya seorang auditor memberi layanan audit kepada klien. Untuk dapat meningkatkan kualitas dan independensi auditor memerlukan adanya rotasi auditor. Rotasi auditor ini terkait dengan aktivitas perusahaan untuk melakukan auditor switching. Auditor switching merupakan pergantian Kantor Akutan Publik (KAP) atau auditor yang dilakukan oleh klien perusahaan. Penelitian ini bertujuan untuk mengetahui pengaruh opini audit, financial distress, pertumbuhan perusahaan klien, dan pergantian manajemen terhadap auditor switching. Penelitian ini merupakan jenis penelitian kuantitatif. Jenis data yang digunakan berupa laporan keuangan yang diperoleh dari www.idx.co.id. Metode analisis data yang digunakan adalah analisis regresi logistik. Populasi dalam penelitian ini adalah perusahaan manufaktur yang terdaftar di Bursa Efek Indonesia dengan metode purposive sampling. Hasil penelitian ini menunjukan bahwa opini audit berpengaruh signifikan terhadap auditor switching. sedangkan financial distress, pertumbuhan perusahaan klien, dan pergantian manajemen tidak berpengaruh signifikan terhadap auditor switching.
\end{abstract}

Kata Kunci : Opini Audit, Financial Distress, Pertumbuhan Perushaan, Pergantian Manajemen, dan Auditor Switching.

\section{abstract}

The Issue of auditor independence is a major issue that a major issue that arises due to the length of an auditor providing auditor to clients. To improve the quality and independence of auditors requires a auditor rotation. The auditor rotation related to the company activity for doing auditor switching. The auditor switching is the replacement of the Public Accounting Firm (KAP) or auditor conducted by the company's clients. This study aims to determine the effect of audit opinion, financial distress, client company growth, and management change on auditor switching. This research is a type of quantitative study. The type of data used is secondary data obtained from www.idx.co.id. The data analysis method used is logistic regression analysis using SPSS version 23. The population in this study are manufacturing companies listed on the Indonesia Stock Exchange during the period 2013-2017. While the sample used in this study was determined by purposive sampling method so that a total of 120 data can be processed. The results of this study indicate that audit opinions have a significant effect on auditor switching. while financial distress, client company growth, and management change do not have a significant effect on auditor switching.

Keywords : Audit Opinion, Financial Distress, Company's Growth, Management Change, and Auditor Switching 


\section{PENDAHULUAN}

\section{A. Latar Belakang}

Auditor yang terlibat hubungan pribadi dengan klien akan menyebabkan hilangnya independensi, dikarenakan hal tersebut dapat mempengaruhi sikap mental dan opini yang diberikan auditor oleh karena itu independensi seorang auditor merupakan kunci utama dari proses audit termasuk untuk menilai kewajaran dari laporan keuangan (Nasser et al., 2006). Hal ini dikarenakan bahwa auditing memberi nilai tambah bagi laporan keuangan perusahaan, karena akuntan publik sebagai pihak yang ahli dan independent (Soekrisno, 2012).

Dengan demikian, untuk menghasilkan laporan keuangan yang handal, maka perusahaan klien diwajibkan untuk melakukan rotasi audit. Pergantian auditor dapat dibedakan menjadi pergantian auditor secara mandatory (wajib) dan pergantian auditor voluntary (sukarela) (Priyatna dan Pramono, 2015). Auditor switching secara mandatory dilakukan hanya berdasarkan peraturan yang berlaku, yang membatasi audit tenure dengan tujuan untuk menjaga independensi auditor. Sedangkan auditor switching yang dilakukan secara voluntary merupakan keputusan yang hanya berdasar keinginan dari perusahaan itu sendiri, diluar peraturan yang ada. Auditor switching secara voluntary ini dapat di latar belakangi oleh berbagai macam faktor (Dwiyanti dan Sabeni, 2012).

Perarturan Pemerintah No. 20 tahun 2015 tentang Praktik Akuntan Publik, tidak memberikan batasan waktu bagi Kantor Akuntan Publik dalam mengaudit suatu entitas. Hal ini turut berperan serta menyebabkan perusahaan klien perlu untuk melakukan pergantian auditor (auditor Switching), yaitu selain untuk meningkatkan kualitas hasil audit atas laporan keuangan perusahaan klien, juga untuk memenuhi peraturan dan ketentuan yang berlaku (Divianto, 2011).

Opini audit adalah pernyataan atau pendapat yang diberikan oleh auditor dan pernyataan atau pendapat diberikan agar perusahaan mengetahui tentang kewajaran laporan keuangannya (Putra, 2014). Opini audit dapat memicu klien untuk mengganti auditornya ketika klien tidak setuju dengan opini audit tahun sebelumnya yang diberikan oleh auditor (Fitriani dan Zulaikha, 2014). Penelitian yang di lakukan oleh Luthfiyati (2016), Faradila dan Yahya (2016), serta Darmayanti (2017) menemukan bahwa opini audit berpengaruh terhadap auditor switching. Tetapi dalam penelitian yang dilakukan oleh Salim (2014) menemukan bahwa opini audit tidak berpengaruh signifikan terhadap auditor switching, serta Putra dan Trisnawati (2016), serta Wea dan Murdiawati (2015) menemukan bahwa opini audit tidak berpengaruh terhadap auditor switching.

Financial distress yang dialami perusahaan terjadi ketika perusahaan tersebut tidak dapat memenuhi kewajiban finansialnya dan terancam bangkrut. Pergantian auditor juga bisa disebabkan karena perusahaan harus menjaga stabilitas finansialnya, sehingga perusahaan mengalami kebijakan subyektif dalam memilih Kantor Akuntan Publik. Keadaan seperti ini mengakibatkan perusahaan cenderung melakukan pergantian KAP (Salim, 2014). Hal ini dilakukan karena untuk mempertahankan kelangsungan hidup perusahaan. Salim (2014), Wea dan Murdiawati (2015), serta Manto dan Manda (2018) menemukan bahwa financial distress memiliki pengaruh signifikan terhadap auditor switching. Sedangkan Faradila dan Yahya (2016), Darmayanti (2017), serta Hidayati (2018) menemukan bahwa financial distress tidak berpengaruh terhadap auditor switching.

Seiring dengan pertumbuhan perusahaan, maka akan semakin kompleks kegiatan operasi perusahaan dan cenderung membutuhkan auditor yang berkualitas. Perusahaan akan melakukan pergantian auditor apabila auditor lama tidak dapat memenuhi kebutuhan perusahaan (Gunady dan Mangoting, 2013). Selain itu, dalam penelitian sebelumnya telah mengidentifikasi banyak alasan untuk pergantian auditor, seperti pertumbuhan bisnis atau untuk persyaratan prosedur yang baru. Ketika perusahaan memerlukan audit lebih kompleks, mungkin perlu untuk memilih auditor yang berbeda (Weiner, 2012). Terdapat hasil penelitian yang kontradiktif mengenai pengaruh pertumbuhan perusahaan klien terhadap auditor switching. Faradila dan Yahya 
(2016), Soraya dan Haridhi (2017), serta Hidayat (2018) menemukan bahwa pertumbuhan perusahaan klien berpengaruh terhadap auditor switching. Akan tetapi, hasil penelitian tersebut bertolak belakang dengan hasil penelitian Putra dan Trisnawati (2016) yang menemukan bahwa pertumbuhan perusahaan tidak berpengaruh terhadap keputusan perusahaan untuk melakukan pergantian auditor.

Selain itu, berubahnya struktur manajemen merupakan hal yang biasa terjadi, terutama untuk perusahaan-perusahaan go public (Paradhana dan Suputra, 2015). Pergantian perubahan manajemen suatu perusahaan dapat menimbukan adanya perubahan dalam kebijakan perusahaan serta dalam hal pemilihan KAP (Luthfiyati, 2016). Manajemen yang baru melakukan auditor switching mungkin karena adanya faktor yang menimbulkan permintaan untuk melakukan auditor switching. Penelitian Manto dan Manda (2018), Luthfiyati (2016), Wea dan Murdiawati (2015), serta Hidayati (2018) menemukan bahwa pergantian manajemen berpengaruh positif terhadap auditor switching. Sedangkan pada penelitian Putra dan Trisnawati (2016), Darmayanti (2017), serta Soraya dan Haridhi (2017) menemukan bahwa pergantian manajemen tidak berpengaruh positif terhadap auditor switching.

\section{TINJAUAN LITERATUR}

\section{A. Tinjauan Pustaka}

\section{Auditor Switching}

Auditor switching merupakan perpidahan KAP yang dilakukan oleh perusahaan karena adanya kewajiban rotasi auditor maupun KAP. Auditor switching dimaksudkan untuk menjaga independensi auditor agar selalu objektif dalam mengaudit laporan keuangan klien. Auditor switching dapat terjadi secara mandatory (wajib) maupun secara voluntary (sukarela). Auditor switching yang bersifat mandatory terjadi disebabkan karena melaksanakan kewajiban dari ketentuan regulasi yang berlaku. Hal ini terjadi jika perusahaan mengganti KAP yang telah mengaudit perusahaan selama masa yang telah ditetapkan, karena hal tersebut bersifat memaksa dan perusahaan melakukan hal ini karena ingin mematuhi peraturan wajib yang telah ditetapkan dan berlaku di Indonesia. Auditor switching bersifat voluntary terjadi karena suatu alasan atau terdapat faktor-faktor tertentu dari pihak perusahaan klien maupun dari KAP yang bersangkutan di luar ketentuan regulasi yang berlaku (Soraya dan Haridhi, 2017).

Auditor switching dapat dilakukan secara mandatory atau dengan voluntary diluar peraturan yang ada. Ketika perusahaan melakukan auditor switching secara voluntary, terdapat dua kemungkinan atas keputusan tersebut yaitu: Perusahaan memberhentikan auditor atau auditor yang dengan sengaja mengundurkan diri (Soraya dan Haridhi, 2017).

Pergantian auditor secara sukarela (voluntary auditor switching) terjadi apabila klien mengganti auditornya tanpa ada peraturan yang mewajibkan klien untuk melakukan pergantian auditor. Voluntary auditor switching ini menimbulkan pertanyaan bagi banyak pihak akan alasan perusahaan mengganti auditor tanpa ada peraturan yang mengharuskannya berpindah auditor (Faradila dan Yahya, 2016). Fitriani dan Zulaikha (2014) menyebutkan bahwa pergantian auditor secara tiba-tiba akan menimbulkan kecurigaan dari para pemakai informasi akuntansi, dan hal itu akan membuat para pemakai informasi mempertanyakan hal apa yang mendasari perusahaan melakukan voluntary auditor switching.

Pergantian auditor bisa terjadi secara voluntary (sukarela) atau secara mandatory (wajib). Jika pergantian auditor terjadi secara voluntary, maka faktor-faktor penyebab dapat berasal dari sisi klien (misalnya kesulitan keuangan, manajemen yang gagal, perubahan ownership, Initial Public Offering, dan sebagainya) dan dari sisi auditor (misalnya fee audit, kualitas audit, dan sebagainya). Sebaliknya, jika pergantian terjadi secara mandatory, seperti yang terjadi di Indonesia, hal itu terjadi karena sudah ada peraturan yang mewajibkan (Febrianto, 2009). 


\section{Opini Audit}

Opini audit adalah pernyataan atau pendapat yang diberikan oleh auditor dan pernyataan atau pendapat diberikan agar perusahaan mengetahui tentang kewajaran laporan keuangannya (Putra, 2014). Opini audit diberikan oleh auditor melalui beberapa tahap audit sehingga auditor dapat mengambil kesimpulan atas opini yang harus diberikan atas laporan keuangan yang di audit (Faradila dan Yahya, 2016).

Gunady dan Mangoting (2013) juga menyatakan bahwa Opini audit merupakan pernyataan pendapat yang diberikan oleh auditor dalam menilai kewajaran penyajian nilai-nilai material dalam sebuah laporan keuangan perusahaan yang diauditnya. Opini audit dinyatakan dalam paragraf pendapat dalam sebuah laporan audit. Dalam Standar Profesional Akuntan Publik dijelaskan bahwa tujuan audit atas laporan keuangan oleh auditor independen adalah untuk menyatakan pendapat tentang kewajaran mengenai semua hal yang material, posisi keuangan, hasil usaha, perubahan ekuitas, dan arus kas sesuai dengan akuntansi yang berlaku umum di Indonesia.

Opini audit merupakan salah satu faktor yang dapat menyebabkan perusahaan melakukan Voluntary auditor switching. Hendricson dan Espahbodi (1991) dalam Faradila dan Yahya (2016) menyatakan bahwa isu yang sangat sensitif dalam hubungan auditor switching adalah kualifikasi opini audit, terutama dimana salah satu tujuan manajemen adalah menerima opini wajar tanpa pengecuallian dari auditor. Manajemen tentu sangat menyukai unqualified opinion untuk menarik investor. Menurut (Gunady dan Mangoting, 2013) Perusahaan akan terus mencari auditor yang akan memberikan opini yang sesuai dengan harapannya (opinion shopping) dan selama itu perusahaan akan terus memberhentikan auditor yang tidak sesuai harapan.

\section{Financial Distress}

Financial distress sebagai salah satu unsur perusahaan melakukan auditor switching. Financial distress terjadi sebelum kebangkrutan terjadi (Almilia dan Kristijadi, 2003 dalam Darmayanti, 2017). Financial distress merupakan kondisi perusahaan yang sedang dalam keadaan kesulitan keuangan (Muid dan Astrini, 2013). Priambardi dan Haryanto (2014) menyatakan bahwa perusahaan terancam bangkrut lebih sering melakukan auditor switching karena mereka berada dalam kondisi tidak stabil dalam bisnis, yang biasanya auditor akan mengeluarkan pendapat. Pendapatnya sesuai dengan keadaan perusahaan yang sedang mengalami financial distress. Auditor cenderung meningkatkan evaluasi subjektivitas dan prinsip kehati-hatian. Institut Akuntan Publik Indonesia (2011:28) menyatakan bahwa Pertimbangan auditor atas kemampuan entitas dalam mempertahankan kelangsungan hidupnya memberikan panduan bagi auditor dalam mengevaluasi kemampuan entitas mempertahankan kelangsungan hidupnya. Prosedur audit yang digunakan auditor misalnya dengan melakukan analisis rasio utang entitas.

Kondisi financial distress perusahaan didefinisikan sebagai kondisi di mana hasil operasi perusahaan tidak cukup untuk memenuhi kewajiban perusahaan (Insolvency) (Gunady dan Mangoting, 2013). Kondisi keuangan perusahaan akan berpengaruh besar pada setiap keputusan perusahaan yang menyangkut pengeluaran kas, salah satunya pengeluaran perusahaan dalam menyewa auditor yang mengaudit perusahaan tersebut. perusahaan dengan kondisi keuangan baik tidak akan kesulitan membiayai pengauditan yang dibutuhkan perusahaan namun berbeda dengan perusahaan yang sedang mengalami kondisi kesulitan dalam keuangannya, perusahaan tentu akan memilih KAP dengan biaya audit yang lebih rendah untuk mengurangi biaya audit yang akan dikeluarkan perusahaan. Ini menyebabkan perusahaan dengan kondisi kesulitan keuangan kemungkinan akan melakukan auditor switching untuk mengurangi biaya yang akan dikeluarkan dalam menyewa auditor eksternal (Sianipar, 2015). 
Kondisi kesulitan keuangan perusahaan sebuah perusahaan memang belum tentu berakhir dengan kebangkrutan, namun dengan adanya kondisi kesulitan keuangan tersebut dapat memberikan peringatan dini akan kondisi perusahaan di masa mendatang (Sianipar, 2015). Informasi Financial distress ini dapat dijadikan sebagai peringatan dini atas kebangkrutan sehingga manajemen dapat melakukan tindakan secara cepat untuk mencegah masalah sebelum terjadinya kebangkrutan (Manto dan Manda, 2018).

\section{Pertumbuhan Perusahaan Klien}

Pertumbuhan perusahaan dapat dinilai baik dimana perusahaan memiliki kemampuan mempertahankan posisi ekonominya pada kegiatan perusahaan (Putra dan Trisnawati, 2016). Nazri et al., (2012) menyatakan bahwa sebuah perjanjian kontraktual baru mungkin perlu dibuat karena ada kemungkinan perusahaan yang berkembang akan membawa manajemen yang baru atau perusahaan mungkin perlu memperkerjakan lebih banyak karyawan, yang pada gilirannya akan menghasilkan pengendalian menjadi lebih jauh.

Seiring dengan pertumbuhan perusahaan, maka akan semakin kompleks kegiatan operasi perusahaan dan cenderung membutuhkan auditor yang berkualitas. Perusahaan akan melakukan pergantian auditor apabila auditor lama tidak dapat memenuhi kebutuhan perusahaan (Gunady dan mangoting, 2013).

Perusahaan yang terus tumbuh akan cenderung untuk melakukan pergantian auditor karena membutuhkan auditor yang memiliki kualitas lebih baik. Pertumbuhan perusahaan yang cepat tentu akan diiringi dengan perubahan manajemen dan juga harus diimbangi oleh auditor yang lebih berkualitas dan memiliki kemampuan sesuai dengan pertumbuhan perusahaan. Ketika bisnis perusahaan sedang bertumbuh, permintaan akan independensi yang lebih tinggi dan perusahaan audit yang lebih berkualitas dibutuhkan untuk mengurangi biaya keagenan serta memberikan layanan non-audit yang dibutuhkan untuk meningkatkan perluasan perusahaan. Pergantian auditor ini juga dianggap oleh perusahaan sebagai suatu keharusan demi meningkatkan prestige perusahaan dan para pemegang saham, serta memberi sinyal kepada pihak luar bahwa perusahaan mereka sangat terpercaya sehingga menarik minat pihak luar perusahaan untuk berinvestasi pada perusahaan klien (Faradila dan Yahya, 2016).

\section{Pergantian Manajemen}

Berubahnya struktur manajemen merupakan hal yang biasa terjadi, terutama untuk perusahaan-perusahaan go public (Pradhana dan Suputra, 2015). Perubahan manajemen adalah pergantian direktur perusahaan yang dapat disebabkan oleh keputusan Rapat Umum Pemegang Saham (RUPS) atau direktur berhenti karena kemauannya sendiri (Damayanti dan Sudarma, 2008 dalam Darmayanti, 2017). Pergantian manajemen disebabkan karena keputusan rapat umum pemegang saham atau pihak manajemen berhenti karena kemauan sendiri sehingga pemegang saham harus mengganti manajemen yang baru yaitu, direktur utama atau CEO (Chief Executive Officer) (Pradhana dan Suputra, 2015). Adanya manajemen yang baru mungkin juga diikuti oleh perubahan kebijakan dalam bidang akuntansi, keuangan dan pemilihan Kantor Akuntan Publik. Manajemen memerlukan auditor yang lebih berkualitas dan mampu memenuhi tuntutan pertumbuhan perusahaan yang cepat (Hidayati, 2018).

Sinarwati (2010) dalam Soraya dan Haridhi (2017) menyatakan bahwa umumnya manajemen akan memberhentikan auditornya secara voluntary apabila auditor tersebut tidak bisa memberikan opini seperti apa yang diharapakan oleh perusahaan, lalu perusahaan akan mencari KAP yang selaras dengan kebutuhan perusahaannya. Sehingga, semakin selaras KAP dengan kebijakan dan pelaporan akuntansi suatu perusahaan maka akan semakin kecil kemungkinan perusahaan untuk berpindah KAP. Sebaliknya, jika KAP tidak bisa memenuhi tuntutan pertumbuhan perusahaan yang cepat maka kemungkinan besar perusahaan akan berhenti menggunakan KAP-nya saat ini. 


\section{B. Kerangka Pemikiran} berikut :

Kerangka pemikiran yang mendasari penelitian ini dapat digambarkan sebagai

\section{Gambar 1. Kerangka Pemikiran}

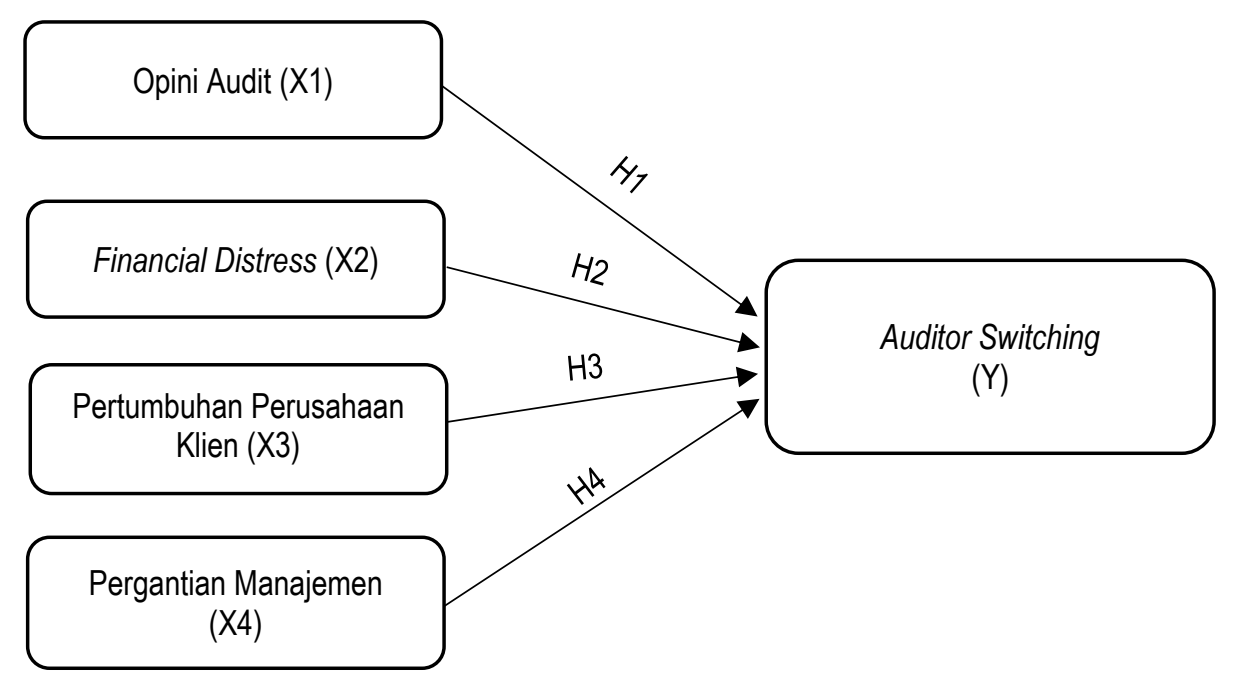

Sumber : Faradila dan Yahya (2016), serta Manto dan Manda (2018).

\section{Pengembangan Hipotesis}

Pengembangan hipotesis yang berkaitan dengan beberapa faktor yang dihubungkan dengan opini audit, financial distress, pertumbuhan perusahaan klien, dan pergantian manajemen yang telah dilakukan oleh beberapa peneliti. Hasil penelitian mengenai beberapa peneliti akan digunakan sebagai bahan referensi dan perbandingan dalam penelitian ini, antara lain adalah sebagai berikut :

\section{Pengaruh Opini Audit terhadap Auditor Switching}

Opini audit adalah pernyataan atau pendapat yang diberikan oleh auditor dan pernyataan atau pendapat diberikan agar perusahaan mengetahui tentang kewajaran laporan keuangannya (Putra 2014). Oleh karena itu laporan keuangan yang di audit akan menghasilkan opini audit melalui tahapan-tahapan audit dan menelaah bukti-bukti yang diperoleh sehingga dapat memperkuat pendapatnya. Opini audit dapat menjadikan salah satu terjadinya auditor switching karena dapat dimungkinkan perusahaan akan mengganti Kantor Akuntan Publik (KAP) jika opini yang di berikan tidak sesuai dengan keinginan klien, karena salah satu tujuan manajemen adalah menerima opini Wajar Tanpa Pengecualian (WTP) dari auditor untuk menarik investor.

Opini audit terkait teori agensi, manajemen sebagai pihak agent diasumsikan mempunyai kepentingan pribadi dan ingin memaksimumkan kepentingannya (Dwiyanti dan Sabeni, 2012). Tugas auditor sebagai pihak ketiga yang independen untuk menyelesaikan konflik antara agen dan prinsipal untuk memberikan opini atas kewajaran laporan keuangan (Darmayanti, 2017). Manajamen tentunya menginginkan opini yang sempurna yang dapat menarik investor. Dengan otoritas yang dimiliki, manajemen dapat memutuskan untuk mengganti auditor. Hal ini dilakukan karena manajemen menganggap dengan melakukan auditor switching, perusahaan dapat menemukan auditor yang mempunyai pandangan yang lebih sejalan (Dwiyanti dan Sabeni, 2012). Gunady dan Mangoting (2013) menyatakan, perusahaan akan terus mencari auditor yang akan memberikan opini yang sesuai dengan harapannya (opinion shopping) dan selama itu perusahaan akan terus memberhentikan auditor yang tidak sesuai harapan. 
Hal ini didukung sesuai dengan penelitian Faradila dan Yahya (2016), Darmayanti (2017), serta Luthfiyati (2016) yang menyatakan bahwa opini audit berpengaruh terhadap auditor switching karena jika opini yang diberikan auditor tidak sesuai keinginan klien, maka perusahaan cenderung akan berpindah KAP yang dapat memberikan opini yang mereka harapkan. Klien yang sudah menerima WTP tidak akan mengganti auditornya sampai batas waktu yang telah di tetapkan pemerintah pada peraturan pemerintah yaitu PP No.20 tahun 2015 pasal 11 tentang Praktik Akuntan Publik, karena opini tersebut sudah sesuai harapan. Berdasarkan uraian diatas, dapat dirumuskan hipotesis sebagai berikut:

Ha1 : Opini Audit berpengaruh terhadap Auditor Switching

\section{Pengaruh Financial Distress terhadap Auditor Switching}

Financial distress merupakan kondisi perusahaan yang sedang dalam keadaan kesulitan keuangan (Muid dan Astrini, 2013). Financial distress sebagai salah satu unsur perusahaan melakukan auditor switching. Financial distress terjadi sebelum kebangkrutan terjadi (Almilia dan Kristijadi, 2003 dalam Darmayanti, 2017). Perusahaan terancam bangkrut lebih sering melakukan auditor switching karena mereka berada dalam kondisi tidak stabil dalam bisnis, yang biasanya auditor akan mengeluarkan pendapat. Pendapatnya sesuai dengan keadaan perusahaan yang sedang mengalami financial distress. Auditor cenderung meningkatkan evaluasi subjektivitas dan prinsip kehati-hatian (Priambardi dan Haryanto, 2014).

Kondisi seperti ini auditor switching juga bisa disebabkan karena perusahaan sudah tidak lagi memiliki kemampuan untuk membayar biaya audit yang bebankan oleh KAP yang diakibatkan penurunan kemampuan keuangan perusahaan. Hal ini dapat melakukan perubahaan dan pergantian auditor dari Kantor Akuntan Publik (KAP) yang berposisi pada big-four dengan memakai jasa auditor dari Kantor Akuntan Publik (KAP) yang non big-four.

Financial distress terkait dengan biaya teori agensi adalah agent yang ditentukan oleh principal untuk jumlah aktivitas yang dilakukan dalam laporan keuangan yang diaudit. (Darmayanti, 2017). Berdasarkan teori agensi yang mengasumsikan bahwa manusia itu self interest, maka pihak agen cenderung berpindah kepada KAP yang dapat menyesuaikan dengan kondisi keuangan perusahaan sehingga perusahaan tidak mengeluarkan biaya audit yang terlalu besar (Fitriani dan Zulaikha, 2014).

Hal ini didukung sesuai dengan penelitan Manto dan Manda (2018), Salim (2014), serta Wea dan Murdiawati (2015) yang menyatakan bahwa financial distress berpengaruh terhadap auditor switching karena semakin tinggi financial distress suatu perusahaan mendorong perusahaan tersebut untuk cenderung mengganti auditornya di bandingkan perusahaan yang tingkat financial distress-nya lebih rendah karena biaya audit yang besar bisa mempengaruhi keputusan perusahaan untuk beralih KAP yang baru yang biaya auditnya lebih kecil. Berdasarkan uraian diatas, dapat dirumuskan hipotesis sebagai berikut :

Ha2 : Financial Distress berpengaruh terhadap Auditor Switching

\section{Pengaruh Pertumbuhan Perusahaan Klien terhadap Auditor Switching}

Pertumbuhan laba perusahaan menunjukkan kemampuan tingkat kekuatan dari perusahaan mengindikasikan kemampuan perusahaan dalam mempertahankan kelangsungan usahanya. Pertumbuhan perusahaan dapat dinilai baik dimana perusahaan memiliki kemampuan mempertahankan posisi ekonominya pada kegiatan perusahaan (Putra dan Trisnawati, 2016). Perusahaan yang terus tumbuh akan cenderung untuk melakukan pergantian auditor karena membutuhkan auditor yang memiliki kualitas lebih baik (Faradila dan Yahya, 2016). Dengan demikian seiring dengan pertumbuhan perusahaan, maka akan semakin kompleks kegiatan operasi perusahaan dan cenderung membutuhkan auditor yang berkualitas. Perusahaan akan melakukan pergantian auditor apabila auditor lama tidak dapat memenuhi kebutuhan perusahaan (Gunady dan mangoting, 2013). Hal ini juga untuk meningkatkan 
prestige perusahaan dan para pemegang saham, serta menarik kepercayaan investor sehingga melakukan investasi pada perusahaan klien.

Teori agensi berkaitan erat dengan pertumbuhan perusahaan, karena ketika perusahaan tumbuh maka akan meningkat juga kesulitan pemilik perusahaan dalam memantau tindakan manajer sebagai principle dan agent. Ini menyebabkan manajemen sebagai agent cenderung memilih auditor yang lebih besar dan memiliki kualitas tinggi karena dianggap mampu memenuhi kebutuhan principle dan agent (Soraya dan Haridhi, 2017).

Hal ini di dukung dengan penelitian Faradila dan Yahya (2016), Hidayati (2018), serta Soraya dan Haridhi (2017) yang menyatakan bahwa pertumbuhan perusahaan berpengaruh terhadap auditor switching karena semakin tinggi pertumbuhan perusahaan klien maka tindakan auditor switching juga meningkat, hal ini di lakukan untuk mendapatkan pertumbuhan perusahaan, meningkatkan reputasi perusahaan, mendapatkan kepercayaan pemegang saham, dan menarik para calon investor untuk berinvestasi. Berdasarkan uraian diatas, dapat dirumuskan hipotesis sebagai berikut :

Ha3 : Pertumbuhan Perusahaan Klien berpengaruh terhadap Auditor Switching

\section{Pengaruh Pergantian Manajemen terhadap Auditor Switching}

Pergantian manajemen disebabkan karena keputusan rapat umum pemegang saham atau pihak manajemen berhenti karena kemauan sendiri sehingga pemegang saham harus mengganti manajemen yang baru yaitu direktur utama atau CEO (Chief Executive Officer) (Pradhana dan Suputra, 2015). Adanya manajemen yang baru mungkin juga diikuti oleh perubahan kebijakan dalam bidang akuntansi, keuangan dan pemilihan Kantor Akuntan Publik. Manajemen memerlukan auditor yang lebih berkualitas dan mampu memenuhi tuntutan pertumbuhan perusahaan yang cepat (Hidayati, 2018). Manajemen yang baru melakukan auditor switching mungkin karena melihat kinerja auditor tahun sebelumnya sehingga manajemen yang baru akan mempertimbangkan mencari auditor yang lebih berkualitas, dan dapat diajak kerjasama serta sejalan dengan kebijakan dalam bidang akuntansi dengan menghasilkan opini yang diharapkan manajemen.

Faktor yang terkait dengan perubahan manajemen dengan teori agensi yaitu konflik antara pemegang saham dan manajemen yang menyebabkan terjadinya pergantian manajemen baru yang dilakukan oleh prinsipal. Mereka menginginkan manajemen baru untuk mendukung keinginan pemegang saham di mana manajemen baru umumnya akan menerapkan metode akuntansi baru (Darmayanti, 2017).

Hal ini di dukung dengan penelitian Manto dan Manda (2018), Hidayati (2018), Luthfiyati (2016), serta Wea dan Murdiawati (2015) yang menyatakan bahwa pergantian manajemen berpengaruh terhadap auditor switching karena pergantian manajemen yang dilakukan oleh perusahaan maka akan menimbulkan perubahan dalam kebijakan perusahaan termasuk kebijakan dalam pemilihan KAP sehingga dapat mendorong terjadinya auditor switching karena manajemen perusahaan cenderung mencari KAP yang selaras dalam pelaporan dan kebijakan akuntansinya serta memilih auditor yang lebih berkualitas dan kompeten untuk melakukan penugasan audit atas laporan perusahaan klien. Berdasarkan uraian diatas, dapat dirumuskan hipotesis sebagai berikut :

Ha4 : Pergantian Manajemen berpengaruh terhadap Auditor Switching

\section{A. Jenis Penelitian}

\section{METODE PENELITIAN}

Jenis data yang digunakan dalam penelitian ini adalah skunder, berupa laporan keuangan auditan perusahaan manufaktur yang listing di Bursa Efek Indonesia. Dalam penelitian ini, menjelaskan hubungan antara variabel dengan pengujian hipotesis. Pada penelitian initerfokus 
pada pengaruh opini audit, financial distress, pertumbuhan perusahaan klien, dan pergantian manajemen terhadap auditor switching.

\section{B. Definisi Oprasional Variabel}

1. Variabel Dependen (Y)

Menurut Sekaran (2011:116), variabel dependen atau variabel terikat adalah variabel yang menjadi perhatian utama peneliti. Variabel dependen dalam penelitian ini adalah Voluntary auditor switching. Voluntary auditor switching adalah perpindahan auditor Kantor Akuntan Publik (KAP) yang dilakukan oleh perusahaan klien secara sukarela tanpa ada peraturan yang mengharuskan klien untuk melakukan pergantian auditor. Variabel auditor switching merupakan variabel dummy. Jika perusahaan melakukan voluntary auditor switching maka akan diberi angka 1, sedangkan jika perusahaan tidak melakukan voluntary auditor switching maka akan diberi angka 0 (Faradila dan Yahya, 2016)

\section{Variabel Independen $(\mathrm{X})$ \\ a. Opini Audit}

Opini audit merupakan pernyataan pendapat yang diberikan oleh auditor dalam meneliti kewajaran laporan keuangan yang di auditnya. Variabel opini audit merupakan variabel dummy. Jika perusahaan klien menerima opini wajar tanpa pengecualian (unqualified opinion) dan wajar tanpa pengecualian dengan tambahan bahasa penjelas (unqualified opinion with explanatory paragraph) maka akan diberi nilai 1. Jika perusahaan klien menerima opini selain unqualified opinion dan unqualified opinion with explanatory paragraph maka akan diberi nilai 0 (Faradila dan Yahya, 2016).

\section{b. Financial Distress}

Financial distress menunjukkan kesulitan solvabilitas perusahaan dimana perusahaan kesulitan dalam melunasi kewajibannya. Apabila perusahaan tidak menunjukkan prospek yang baik, maka langkah terakhir yang harus ditempuh adalah likuidasi. Financial distress dapat dirumuskan sebagai berikut :

Keterangan :

$$
\text { DAR }=\frac{\text { Total Hutang }}{\text { Total Aset }}
$$

\section{$\mathrm{DAR}=$ Debt to asset ratio}

\section{c. Pertumbuhan Perusahaan Klien}

Pertumbuhan perusahaan merupakan ukuran seberapa baik perusahaan mempertahankan kondisi finansialnya, baik dalam industrinya maupun dalam kegiatan ekonomi secara keseluruhan (Weston dan Copeland, 1992 dalam Faradila dan Yahya, 2016). Faradila dan Yahya (2016) menyatakan bahwa pertumbuhan perusahaan diproksikan dengan tingkat penjualan pada suatu perusahaan. Semakin tinggi tingkat penjualan perusahaan maka akan semakin tinggi pula kemungkinan perusahaan untuk melakukan voluntary auditor switching. Rasio pertumbuhan perusahaan klien dapat dirumuskan sebagai berikut :

Keterangan :

$$
\mathrm{d} S=\frac{S_{t}-S_{t-1}}{S_{t-1}}
$$

$$
\begin{array}{ll}
\mathrm{dS} & =\text { Rasio pertumbuhan perusahaan klien } \\
S_{t} & =\text { Penjualan bersih pada tahun pergantian auditor } \\
S_{t-1} & =\text { Penjualan bersih pada tahun sebelum pergantian auditor }
\end{array}
$$

\section{e. Pergantian Manajemen}


Pergantian manajemen adalah pergantian direksi perusahaan yang dilakukan melalui keputusan Rapat Umum Pemegang Saham (RUPS) atau direksi berhenti karena kemauan sendiri. Pergantian manajemen dalam penelitian ini diproksikan dengan pergantian direktur utama. Pergantian Manajemen diukur menggunakan variabel dummy. Jika terdapat pergantian direktur utama dalam perusahaan maka akan diberi nilai 1. Sedangkan, jika tidak terdapat pergantian direktur utama dalam perusahaan, maka diberi nilai 0 (Damayanti dan Sudarma, 2007) dalam Manto dan Manda (2018).

\section{Populasi dan Sampel}

Populasi dalam penelitian ini adalah perusahaan manufaktur yang listing di Bursa Efek Indonesia (BEI). Sampel dalam penelitian ini menggunakan teknik non-probability sampling. Teknik non-probability sampling yang digunakan adalah purposive sampling. Penggunaan teknik purposive sampling ini bertujuan untuk mendapatkan sampel yang sesuai dengan kriteria yang ditentukan.

\section{Teknik Analisis Data}

Analisis yang digunakan dalam penelitian ini menggunakan analisis deskriptif dan regresi logistik, karena variabel dependen bersifat dikotomi (melakukan voluntary auditor switching dan tidak melakukan voluntary auditor switching).

\section{Analisis Koefisien Regresi}

Adapun model regresi logistik yang digunakan dalam penelitian ini adalah sebagai berikut :

$$
\operatorname{Ln} \frac{\mathrm{AS}}{1-\mathrm{AS}}=\beta_{0}+\beta_{1} \mathrm{OA}+\beta_{2} \mathrm{FD}+\beta_{3} \mathrm{PP}+\beta_{4} \mathrm{PM}+\mathrm{e}
$$

(Ghozali, 2016)

Keterangan :

$\begin{array}{ll}\operatorname{Ln} \frac{\mathrm{AS}}{1-\mathrm{AS}} & : \text { Dummy variabel Auditor Switching } \\ \beta_{0} & : \text { Konstanta } \\ \mathrm{OA} & : \text { Opini Audit } \\ \mathrm{FD} & : \text { Financial Distress } \\ \mathrm{PP} & : \text { Pertumbuhan Perusahaan } \\ \mathrm{PM} & : \text { Pergantian Manajemen } \\ \beta_{1-4} & : \text { Konstanta peran X dalam menentukan Y } \\ \mathrm{e} & : \text { Error }\end{array}$

\section{Uji Hipotesis}

\section{a. Estimasi Parameter dan Interprestasinya}

Menurut Ghozali (2016) Estimasi maksimum likelihood parameter dari model dapat dilihat pada tampilan output variabel in the equation. Pengujian hipotesis dilakukan dengan membandingkan antara tingkat signifikansi dengan tingkat kesalahan $(\alpha)=0,05(5 \%)$. Adapun hipotesis yang terbentuk sebagai berikut:

$\mathrm{H}_{0}: \mathrm{B}_{\boldsymbol{i}}=0$. Jika diperoleh nilai sig. $>\alpha$, maka menolak $\mathrm{H}_{\mathrm{a}}$ dan menerima $\mathrm{H}_{0}$, dengan ketentuan variabel $\mathrm{X}$ tidak berpengaruh terhadap variabel $\mathrm{Y}$

$\mathrm{H}_{\mathrm{a}}: \mathrm{B}_{\boldsymbol{i}} \neq 0$. Jika diperoleh nilai sig. $<\alpha$, maka menerima $\mathrm{H}_{\mathrm{a}}$ dan menolak $\mathrm{H}_{0}$, dengan ketentuan variabel $\mathrm{X}$ berpengaruh terhadap variabel $\mathrm{Y}$

Dengan demikian dapat disimpulkan apabila diperoleh sig. $<\alpha$, maka menunjukkan bahwa variabel independen berpengaruh signifikan terhadap variabel dependen. 


\section{A. Hasil Analisis Data}

\section{HASIL DAN DISKUSI}

Data akan dianalisis dengan deskriptif dan uji hipotesis penelitian dengan menggunakan model regresi logistik. Pertama, analisis statistik deskriptif dilakukan untuk mengetahui distribusi data. Kedua, uji hipotesis dengan menggunakan model regresi logistik untuk menguji apakah probabilitas terjadinya variabel dependen dapat diprediksi dengan variabel independen. Variabel independen dalam penelitian ini adalah opini audit, financial distress, pertumbuhan perusahaan klien, dan pergantian manajemen. Sedangkan, variabel dependen dalam penelitian ini adalah auditor switching.

\section{Analisis Statistik Deskriptif}

Analisis statistik deskriptif digunakan untuk memberikan gambaran atau deskripsi suatu data yang dilihat dari nilai minimum, maksimum, rata-rata (mean), dan standar deviasi (standard deviation) dari masing-masing variabel penelitian. Hasil analisis deskriptif dari variabel-variabel penelitian adalah sebagai berikut:

Tabel 1. Statistik Deskriptif

\begin{tabular}{|c|c|c|c|c|c|}
\hline \multicolumn{6}{|c|}{ Descriptive Statistics } \\
\hline & $\mathrm{N}$ & Minimum & Maximum & Mean & Std. Deviation \\
\hline AS & 120 & 0 & 1 & ,47 &, 501 \\
\hline$O A$ & 120 & 0 & 1 & 88 & ,332 \\
\hline FD & 120 & ,074 & 2,767 & ,58100 & 485922 \\
\hline PP & 120 &,- 954 & 5,947 & 13123 & 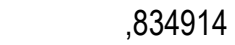 \\
\hline PM & 120 & 0 & 1 & ,12 & ,332 \\
\hline Valid N (listwise) & 120 & & & & \\
\hline
\end{tabular}

Sumber : Data Output SPSS, 2019

\section{Analisis Regresi Logistik (Logistic Regression)}

Pada penelitian ini menggunakan Regresi Logistik (Logistic Regression) dikarenakan variabel dependen bersifat dummy. Regresi Logistik merupakan untuk menguji probabilitas terjadinya variabel terikat (dependen) dapat diprediksi dengan variabel bebasnya (independen). Teknik analisis ini tidak memerlukan lagi uji asumsi normalitas data dan uji asumsi klasik pada variabel bebasnya (Ghozali, 2016). Tahapan dalam pengujian dengna mnggunakan uji regresi logistik dapat dijelaskan sebagai berikut:

\section{a. Menilai Keseluruhan Model (Overall Model Fit)}

Menurut Ghozali (2016) Langkah pertama adalah menilai Keseluruhan Model (Overall Model Fit) terhadap data. Pengujian keseluruhan model (overall model fit) dilakukan dengan membandingkan nilai -2 Log Likelihood pada awal (Block Number=0) dengan nilai -2 Log Likelihood pada akhir (Block Number=1). Hipotesis untuk menilai model fit adalah :

$\mathrm{H}_{0}$ : Model yang dihipotesiskan fit dengan data

$\mathrm{H}_{\mathrm{a}}$ : Model yang dihipotesiskan tidak fit dengan data

Berdasarkan hipotesis ini, maka $\mathrm{H}_{0}$ harus diterima dan $\mathrm{H}_{\mathrm{a}}$ harus ditolak agar model fit dengan data. Statistik yang digunakan berdasarkan pada fungsi likelihood. Likelihood L dari model adalah probabilitas bahwa model yang dihipotesiskan menggambarkan data input (Ghozali, 2016).

Tabel 2 adalah Iteration Historis 0 yang merupakan -2 Log Likelihood awal. Tabel 2 akan dibandingkan dengan tabel 3, tabel Iteration Historis 1 yang merupakan -2 Log Likelihood akhir. Adanya penurunan antara -2 log Likelihood awal dengan -2 Loglihood akhir menunjukkan bahwa hipotesis nol $\left(\mathrm{H}_{0}\right)$ tidak dapat ditolak atau model fit dengan data. 
Tabel 2. Iteration History 0

Iteration Historya,b,c

\begin{tabular}{lrrr}
\multicolumn{3}{c}{ Iteration Historya,b,c } \\
\hline Iteration & -2 Log likelihood & \multicolumn{1}{c}{ Coefficients } \\
\hline Step 0 & 1 & 165,822 &,- 133 \\
& 2 & 165,822 &,- 134 \\
\hline
\end{tabular}

Sumber : Data Output SPSS, 2019

Tabel 3. Iteration History 1 Iteration Historya,b,c,d

\begin{tabular}{lrrrrrrr}
\hline Iteration & & & \multicolumn{7}{c}{ Coefficients } & \multicolumn{2}{l}{} \\
\hline Step 1 1 & 1 & 159,515 & $-1,833$ & 1,504 &, 717 &, 095 &,- 367 \\
& 2 & 159,334 & $-2,217$ & 1,830 &, 848 &, 101 &,- 404 \\
& 3 & 159,333 & $-2,253$ & 1,861 &, 859 &, 102 &,- 407 \\
& 4 & 159,333 & $-2,254$ & 1,861 &, 860 &, 102 &,- 407 \\
\hline
\end{tabular}

Sumber : Data Outputs SPSS, 2019

Berdasarkan tabel 2 menunjukkan bahwa nilai -2 Log Likelihood awal (tabel Iteration History 0) adalah sebesar 165,822 sedangkan pada tabel 3 menujukan nilai -2 Log likelihood akhir (tabel Iteration History 1) adalah sebesar 159,333. Hasil tersebut menunjukan bawa terjadi penurunan nilai antara -2 Log Likelihood awal dan akhir sebesar 6,489. Penurunan ini signifikan atau dapat di bandingkan dengan tabel c2 (critical value two-tailed test) dengan $\mathrm{df}$ (selisih -2 $\log L$ untuk konstanta saja dan -2 $\log L$ untuk model dengan konstanta dan 4 variabel independen) (Ghozali, 2016). $\mathrm{N}=120$, df1 (n-q) = 119 (120 - 1) dan df2 115 (120 - 5). Jadi selisih kedua $-2 \log L$ sebesar 6,489 (165,822 - 159,333) dengan df 4 (119 - 115). Dari tabel c2 df 3 didapat angka 2,776 pada taraf signifikan 0,05. Oleh karena 6,489 lebih besar dari nilai tabel maka dapat diartikan bahwa penambahan variabel independen OA, FD, PP, dan PM ke dalam model regresi memperbaiki model fit, ini menunjukan model regresi yang baik atau dengan kata lain model yang dihipotesiskan fit dengan data.

\section{b. Menilai Kelayakan Model Regresi}

Analisis selanjutnya yang dilakukan adalah menilai kelayakan model regresi logistik. Menilai kelayakan dari model regresi dapat dilakukan dengan memperhatikan goodness of fit yang diukur dengan Chi-Square pada kolom Hosmer and Lemeshow (Ghozali, 2016:329). Hipotesis yang digunakan untuk menilai kelayakan model regresi adalah :

$\mathrm{H}_{0}$ : Tidak ada perbedaan antara model dengan data

$\mathrm{H}_{\mathrm{A}}$ : Ada perbedaan antara model dengan data

Berdasarkan hipotesis ini, maka $\mathrm{H}_{0}$ tidak dapat ditolak dan berarti model dapat memprediksi nilai observasinya atau dapat dikatakan model dapat diterima karena cocok dengan data observasinya (Ghozali, 2016:329).

Tabel 4. Hosmer and Lemeshow Test
Hosmer and Lemeshow Test
\begin{tabular}{|lcccr}
\hline Step & Chi-square & Df & Sig. \\
\hline 1 & 13,302 & 8 &, 102 \\
\hline
\end{tabular}

Sumber : Data Output SPSS, 2019

Berdasarkan tabel di atas dapat diketahui hasil pengujian Hosmer and Lemeshow's Goodness of Fit Test menunjukkan nilai Chi-squere 13.302 dan nilai signifikan sebesar 0,102. Berdasarkan hasil tersebut, nilai signifikan lebih besar dari 0,05 sehingga dapat disimpulkan 
bahwa model mampu memprediksi nilai observasinya atau dapat dikatakan model dapat diterima dan cocok dengan data observasinya.

\section{c. Koefisien Determinasi (Nagelkerke's R Square)}

Koefesien determinasi $\left(\mathrm{R}^{2}\right)$ digunakan untuk mengetahui seberapa besar variabilitas variabel-variabel independen mampu memperjelaskan variabilitas variabel dependen. Koefesien determinasi pada regresi logistik dapat dilihat pada nilai Nagelkerke's $R$ Square. Nilai Nagelkerke's $R$ Square dapat diinterprestasikan seperti nilai $\mathrm{R}^{2}$ pada regresi berganda (multiple regression) (Ghozali, 2016).

\begin{tabular}{lrrrr}
\multicolumn{5}{c}{ Tabel 5. Model Summary } \\
Model Summary
\end{tabular}

Sumber : Data Output SPSS, 2019

Berdasarkan tabel 5 Model Summary, nilai Nagelkerke's $R$ Square adalah sebesar 0,070. Hal ini berarti variasi variabel dependen dapat dijelaskan oleh variable independen dalam penelitian ini adalah sebesar 7\%. Sisanya sebesar 93\% dijelaskan oleh variabel independen lain di luar model penelitian ini.

\section{d. Tabel Klasifiksi}

Tabel klasifikasi menunjukkan kekuatan prediksi dari model regresi untuk memprediksi kemungkinan terjadinya voluntary auditor switching oleh perusahaan. Pada tabel klasifikasi terdapat kolom yang berisi nilai prediksi dari variabel auditor switching, angka nol (0) menunjukan tidak adanya auditor switching dan angka satu (1) menunjukan adanya auditor switching. selain itu terdapat baris yang menunjukan nilai observasi dari variabel auditor switching. adapun dari uji klasifikasi dari model regresi adalah sebagai berikut :

Tabel 6. Classification Table Classification Table ${ }^{a}$

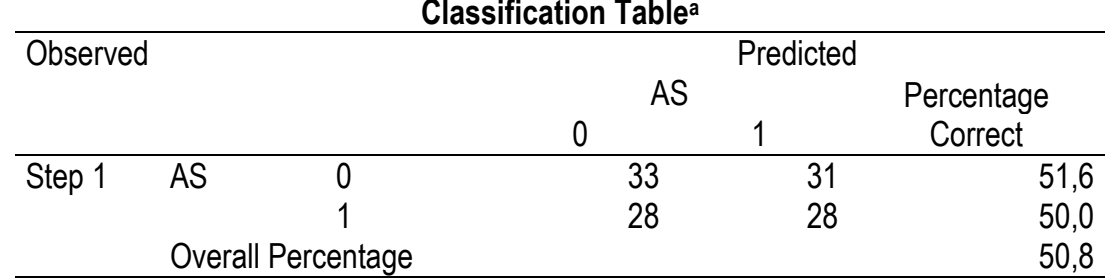

Sumber : Data Output SPSS, 2019

Tabel 6 menunjukkan kekuatan prediksi dari model regresi untuk memprediksi kemungkinan perusahaan dalam melakukan auditor switching pada penelitian ini adalah sebesar 50,8\%. Kekuatan prediksi model perusahaan yang tidak melakukan auditor switching adalah sebesar 51,6\% yang berarti bahwa dengan model regresi yang digunakan ada sebanyak 33 perusahaan yang diprediksi tidak melakukan auditor switching dari total 64 perusahaan yang tidak melakukan auditor switching. selain itu, tabel diatas juga menunjukan bahwa dengan menggunakan model regresi yang digunakan terdapat 28 perusahaan $(50,0 \%)$ yang di prediksi akan melakukan auditor switching dari total 56 perusahaan yang melakukan auditor switching.

\section{Analisis Koefisien Regresi}

Pengujian hipotesis dalam penelitian ini adalah untuk menguji pengaruh variabel independen opini audit, financial distress, pertumbuhan perusahaan klien, dan pergantian 
manajemen terhadap variabel dependen auditor switching dengan menggunakan regresi logistik dan hasil dari penelitian ini ditunjukan pada tabel 4.10.

Tabel 8. Hasil Uji Regresi Logistik

Variables in the Equation

\begin{tabular}{llrrrrrr}
\hline & & \multicolumn{1}{c}{ B } & \multicolumn{1}{c}{ S.E. } & \multicolumn{1}{l}{ Wald } & Df & \multicolumn{1}{c}{ Sig. } & \multicolumn{1}{c}{ Exp(B) } \\
\hline Step 1 & OA & 1,861 &, 893 & 4,346 & 1 &, 037 & 6,429 \\
& FD &, 860 &, 514 & 2,801 & 1 &, 094 & 2,362 \\
& PP &, 102 &, 233 &, 191 & 1 &, 662 & 1,107 \\
& PM &,- 407 &, 579 &, 493 & 1 &, 483 &, 666 \\
& Constant & $-2,254$ & 1,050 & 4,607 & 1 &, 032 &, 105 \\
\hline
\end{tabular}

Sumber : Data Output SPSS, 2019

Tabel 8. menunjukan regresi logistik antara variabel independen dengan variabel dependen. Variabel opini audit (OA) memiliki nilai koefisien positif 1,861. Hal ini menunjukan jika perusahaan mendapatkan opini selain wajar tanpa pengecualian, maka keputusan dalam melakukan auditor switching akan meningkat sebesar 1,861 dengan tingkat signifikan sebesar $0,037(<0,05)$, dengan demikian dapat dikatakan bahwa opini audit berpengaruh positif dan signifikan terhadap auditor switching.

Hasi uji regresi logistik financial distress (FD) memiliki koefisien positif 0,860 . Hal ini menunjukan jika perusahaan mengalami peningkatan tingkat financial distress satu satuan maka keputusan perusahaan dalam melakukan auditor switching akan meningkat sebesar 0,860 dengan tingkat signifikan sebesar 0,094 (>0,05), dengan demikian dapat dikatakan bahwa financial distress tidak berpengaruh terhadap auditor switching.

Hasi uji regresi logistik pertumbuhan perusahaan klien (PP) memiliki koefisien positif 0,102 . Hal ini menunjukan apabila terjadi peningkatan pertumbuhan perusahaan satu satuan, maka keputusan perusahaan dalam melakukan auditor switching akan meningkat sebesar 0,102 dengan tingkat signifikan sebesar 0,662 (>0,05), dengan demikian dapat dikatakan bahwa pertumbuhan perusahaan klien tidak berpengaruh terhadap auditor switching.

Hasi uji regresi logistik pergantian manajemen (PM) memiliki koefisien negatif 0,407. Hal ini menunjukan jika perusahaan melakukan pergantian manajemen, maka keputusan dalam melakukan auditor switching akan menurun sebesar 0,407 dengan tingkat signifikan sebesar 0,483 (> 0,05), dengan demikian dapat dikatakan bahwa pergantian manajemen tidak berpengaruh terhadap auditor switching.

Berdasarkan Tabel 8, maka model regresi yang terbentuk adalah sebagai berikut :

$$
\begin{gathered}
\operatorname{Ln} \frac{\mathrm{AS}}{1-\mathrm{AS}}=\beta_{0}+\beta_{1} \mathrm{OA}+\beta_{2} \mathrm{FD}+\beta_{3} \mathrm{PP}+\beta_{4} \mathrm{PM}+\mathrm{e} \\
\operatorname{Ln} \frac{\mathrm{AS}}{1-\mathrm{AS}}=-2,254+1,861+0,860+0,102-0,407+\mathrm{e}
\end{gathered}
$$

\section{B. Pembahasan Hasil Penelitian}

\section{Pengaruh Opini Audit (OA) Terhadap Auditor Switching (AS)}

Berdasarkan hasil pengujian variabel opini audit terhadap auditor switching yang diukur dengan menggunakan model regresi logistik, diperoleh nilai koefisien positif sebesr 1,861 dengan tingkat signifikan 0,037 berada lebih kecil dari $\alpha=0,05$ (5\%). Maka hipotesis pertama diterima, artinya opini audit berpengaruh positif dan signifikan terhadap auditor switching.

Dengan demikian dalam penelitian ini membuktikan bahwa opini selain wajar tanpa pengecualian berpengaruh terhadap auditor switching, yang berarti ketika perusahaan mendapatkan opini wajar tanpa pengecualian, maka keputusan perusahaan untuk melakukan auditor switching akan semakin rendah karena opini tersebut sudah sesuai dengan yang di harapkan perusahaan. Hal ini menyatakan bahwa kualitas opini audit cukup menentukan perusahaan untuk melakukan auditor switching. 
Opini auditor memberikan informasi yang berguna bagi perusahaan atas laporan keuangan suatu perusahaan yang dapat membantu dalam pengambilan keputusan khususnya para investor. Perusahaan menginginkan opini wajar tanpa pengecualian (unqualified opinion) dari KAP yang mengaudit diperusahaannya, karena dengan opini wajar tanpa pengecualian perusahaan dapat meningkatkan kredibilitas perusahaan dan mampu menarik minat para investor untuk berinvestasi. Jika auditor tidak dapat memberikan opini wajar tanpa pengecualian, maka perusahaan akan berpindah kepada KAP yang mungkin dapat memberikan opini sesuai dengan yang diharapkan oleh perusahaan. Gunady dan Mangoting (2013) menyatakan, perusahaan akan terus mencari auditor yang akan memberikan opini yang sesuai dengan harapannyaa (opinion shopping) dan selama itu perusahaan akan terus memberhentikan auditor yang tidak sesuai harapan.

Hasil penelitian ini sejalan dengan penelitian yang di lakukan oleh Faradila dan Yahya (2016), Darmayanti (2017), dan Luthfiyati (2016), penelitian tersebut menyatakan bahwa opini audit berpengaruh signifikan terhadap auditor switching.

\section{Pengaruh Financial Distress (FD) Terhadap Auditor Switching (AS)}

Hipotesis kedua ini bertujuan untuk menguji apakah terdapat pengaruh antara financial distress terhadap auditor switching. Hasil pengujian regresi logistik diperoleh nilai koefesien positif sebesar 0,860 dengan tingkat signifikan 0,094 berada lebih besar dari $\alpha=0,05(5 \%)$. Maka hipotesis kedua ditolak, artinya financial distress tidak berpengaruh signifikan terhadap auditor switching. Hasil penelitian ini tidak berhasil mendukung hipotesis yang diajukan.

Dengan demikian penelitian ini mengungkapkan bahwa financial distress tidak berpengaruh terhadap auditor switching, yang berarti ketika perusahaan mengalami financial distress, maka keputusan perusahaan untuk melakukan auditor switching sangat kecil karena kondisi keuangan perusahaan tidak stabil. Hal ini menyatakan bahwa kebangkrutan perusahaan tidak cukup untuk menentukan perusahaan melakukan auditor switching.

Perusahaan yang mengalami kesulitan keuangan kemungkinan tidak melakukan auditor switching disebabkan biaya start up yang tinggi apabila perusahaan mengganti KAPnya, sedangkan kondisi perusahaan sedang tidak stabil (Faradila dan Yahya, 2016). Perusahaan yang terlalu sering melakukan pergantian auditor akan meningkatkan fee audit. Ketika pertama kali mengaudit suatu klien, hal pertamma yang dilakukan auditor memahami lingkungan bisnis klien dan risiko audit klien. Sehingga berakibat pada tingginya biaya star up dan menaikan fee audit (Hidayati, 2018). Selain itu, pergantian KAP tidak dalam waktu yang ditentukan didalam peraturan dapat menjadi pertanyaan bagi pemegang saham maupun investor sehingga dalam kondisi perusahaan yang sedang mengalami financial distress dapat menimbulkan tanggapan negatif. Dengan kondisi seperti itu, perusahaan cenderung meningkatkan evaluasi subjektivitas auditor dan untuk menjaga kepercayaan para pemegang saham dan kreditur perusahaan. Menurut Hidayati (2016) penugasan pertama juga akan memungkinkan terjadinya kekeliruan yang tinggi. Suatu usaha untuk menjaga kepercayaan investor dan menarik minatnya untuk berinvestasi adalah menggunakan KAP yang memiliki kemampuan untuk menghasilkan kualitas audit yang lebih tinggi dan lebih independen. Sehingga perusahaan cenderung tidak melakukan auditor switching untuk menjaga kepercayaan para pemegang saham dan kreditur perusahaan.

Hasil penelitian ini sejalan dengan penelitian yang dilakukan oleh Faradila dan Yahya (2016), Darmayanti (2017), dan Hidayati (2018) yang menyatakan bahwa financial distress tidak berpengaruh signifikan terhadap auditor switching. Namun penelitian ini tidak mendukung penelitian Salim (2014), Wea dan Murdiawati (2015), serta Manto dan Manda (2018) yang menyatakan bahwa financial distress berpengaruh signifikan terhadap auditor switching. 


\section{Pengaruh Pertumbuhan Perusahaan Klien (PP) Terhadap Auditor Switching (AS)}

Hipotesis ketiga ini bertujuan untuk menguji apakah terdapat pengaruh antara pertumbuhan perusahaan klien terhadap auditor switching. Hasil pengujian regresi logistik diperoleh nilai koefesien positif sebesar 0,102 dengan tingkat signifikan 0,662 berada lebih besar dari $\alpha=0,05(5 \%)$. Maka hipotesis kedua ditolak, artinya pertumbuhan perusahaan klien tidak berpengaruh signifikan terhadap auditor switching. Hasil penelitian ini tidak berhasil mendukung hipotesis yang diajukan.

Dengan demikian penelitian ini mengungkapkan bahwa pertumbuhan perusahaan klien tidak berpengaruh terhadap auditor switching. Hal ini menunjukan bahwa pertumbuhan perusahaan klien bukan merupakan salah satu faktor yang mendorong perusahaan untuk melakukan auditor switching. Seiring dengan pertumbuhan perusahaan, idealnya klien mengganti auditornya dengan auditor yang lebih bagus agar dapat meningkatkan citra perusahaan yang lebih baik di mata pihak eksternal. Dengan bertumbuhnya perusahaan klien diharapkan klien dapat membayar biaya audit yang lebih tinggi agar kualitas auditnya meningkat (Aprianti dan Hartaty, 2016).

Namun, berdasarkan hasil penelitian ini menunjukan bahwa pertumbuhan perusahaan klien tidak berpengaruh terhadap auditor switching. Hal ini disebabkan karena tingkat penjualan suatu perusahaan tidak naik secara cepat dan berdasarkan observasi bahwa perusahaan sudah di audit oleh KAP yang bagus, yaitu dengan 8\% KAP Big Four, 12\% Big Ten, dan $80 \%$ Non-Big Four dan berafiliasi serta adanya pertimbangan manajemen karena memungkinkan auditor tahun sebelumnya dianggap mampu memenuhi kebutuhan perusahaan dan telah menguasai kegiatan bisnis klien secara mendalam. Selain itu, menurut Nuryanti (2012:17) dalam Aprianti dan Hartaty (2016) manajemen juga mempertimbangkan untuk mempertahankan reputasi perusahaannya dengan tidak mengganti KAP yang mengaudit laporan keuangan perusahaan.

Hasil penelitian ini sejalan dengan penelitian yang dilakukan oleh putra dan Trisnawati (2016) yang menyatakan bahwa pertumbuhan perusahaan klien tidak berpengaruh signifikan terhadap auditor switching. Namun, penelitian ini tidak mendukung penelitian Faradila dan Yahya (2016), Hidayati (2018), dan Soraya dan Haridhi (2017) yang menyatakan bahwa perumbuhan perusahaan klien berpengaruh signifikan terhadap auditor switching.

\section{Pengaruh Pergantian Manajemen (PM) Terhadap Auditor Switching (AS)}

Hipotesis keempat ini bertujuan untuk menguji apakah terdapat pengaruh antara pertumbuhan perusahaan klien terhadap auditor switching. Hasil pengujian regresi logistik diperoleh nilai koefesien negatif sebesar 0,407 dengan tingkat signifikan 0,483 berada lebih besar dari $\alpha=0,05(5 \%)$. Maka hipotesis kedua ditolak, artinya pertumbuhan perusahaan klien tidak berpengaruh signifikan terhadap auditor switching. Hasil penelitian ini tidak berhasil mendukung hipotesis yang diajukan.

Dengan demikian penelitian ini mengungkapkan bahwa pergantian manajemen (CEO) tidak berpengaruh terhadap auditor switching, karena pergantian manajemen tidak selalu di ikuti dengan perubahan kebijakan dari perusahaan yang dilakukan oleh manajer yang baru. Hal ini menyatakan bahwa keputusan pergantian CEO tidak cukup untuk menentukan perusahaan melakukan auditor switching.

Pergantian manajemen disebabkan karena keputusan Rapat Umum Pemegang Saham (RUPS). Hasil penelitian menunjukkan bahwa perubahan manajemen tidak selalu diikuti dengan perubahan kebijakan diperusahaan menggunakan jasa sebuah perusahaan akuntan. Hal ini menunjukkan bahwa kebijakan akuntansi dan pelaporan KAP masih diselaraskan dengan kebijakan manajemen baru dengan cara re-negosiasi antara kedua belah pihak (Darmayanti, 2017). Sehingga semakin selaras KAP dengan kebijakan dan pelaporan akuntansi suatu perusahaan maka akan semakin kecil kemungkinan perusahaan untuk berpindah KAP. Selain 
itu, adanya kewaspadaan dari publik apabila pihak manajemen perusahaan memilih Kantor Akuntan Publik yang baru (Wea dan Murdiawati, 2015).

Hasil penelitian ini sejalan dengan penelitian yang dilakukan oleh Putra dan Trisnawati (2016), Darmayanti (2017), serta Soraya dan Haridhi (2017) yang menyatakan bahwa pergantian manajemen tidak berpengaruh signifikan terhadap auditor switching. Namun, penelitian ini tidak mendukung penelitian Manto dan Manda (2018), Wea dan Murdiawati (2015), serta Hidayati (2018) yang menyatakan bahwa pergantian manajemen berpengaruh signifikan terhadap auditor switching.

\section{A. Simpulan}

\section{SIMPULAN DAN SARAN}

Berdasarkan hasil penelitian serta pembahasan maka dapat disimpulkan bahwa : Opini Audit berpengaruh positif dan signifikan terhadap Auditor Switching. Bahwa opini selain wajar tanpa pengecualian berpengaruh terhadap auditor switching, yang berarti ketika perusahaan mendapatkan opini wajar tanpa pengecualian, maka keputusan perusahaan untuk melakukan auditor switching akan semakin rendah karena opini tersebut sudah sesuai dengan yang di harapkan perusahaan. Financial Distress tidak berpengaruh terhadap Auditor Switching. Perusahaan yang mengalami kesulitan keuangan kemungkinan tidak melakukan auditor switching disebabkan biaya start up yang tinggi apabila perusahaan mengganti KAPnya, sedangkan kondisi perusahaan sedang tidak stabil. Pertumbuhan Perusahaan Klien tidak berpengaruh terhadap Auditor Switching. Manajemen juga mempertimbangkan untuk mempertahankan reputasi perusahaannya dengan tidak mengganti KAP yang mengaudit laporan keuangan perusahaan. Hal ini dikarenakan auditor tahun sebelumnya dianggap mampu memenuhi kebutuhan perusahaan dan telah menguasai kegiatan bisnis klien secara mendalam. Pergantian Manajemen tidak berpengaruh terhadap Auditor Switching. Hal ini menyatakan bahwa keputusan pergantian CEO tidak cukup untuk menentukan perusahaan melakukan auditor switching.

\section{B. Saran}

Dari analisis dan simpulan yang telah diuraikan, penulis memberikan beberapa saran sebagai berikut: Untuk penelitian selanjutnya memperluas objek penelitian pada sektor-sektor lain, tidak hanya sebatas perusahaan manufaktur serta menambah periode pengamatan untuk diperoleh sampel yang lebih banyak. Penelitian selanjutnya juga dapat menambah beberapa variabel lainnya yang diduga dapat mempengaruhi auditor switching baik dari faktor internal maupun eksternal. Seperti : audit fee, ukuran KAP, ukuran perusahaan, audit delay, reputasi auditor, kepemilikan publik, dan ROA. Bagi auditor, peneliti berharap independensi dan objektivitas auditor tetap terjaga, baik auditor yang berasal dari KAP big four maupun auditor yang berasal dari KAP non big four. Bagi perusahaan, sebaiknya lebih berhati-hati dalam mengambil keputusan untuk melakukan auditor switching sehingga mendapatkan auditor yang baru yang lebih berkualitas.

\section{DAFTAR PUSTAKA}

Agoes, Sukrisno. 2012. Auditing. Edisi 4. Jakarta: Salemba Empat.

Darmayanti, Novi. 2017. The Effect of Audit Opinion, Financial Distress, Client Size, Management Turn and KAP Size on Auditor Switching. Journal of Economics, Business, and Accounting Ventura. Vol. 20, No. 2, August-November 2017. 
Divianto. 2011. Faktor-Faktor Yang Mempengaruhi Perusahaan Dalam Melakukan Auditor Switch (Studi Kasus : Perusahaan Manufaktur di BEI). Jurnal Ekonomi dan Informasi Akuntansi (JENIUS). VOL.1, NO.2, MEI 2011.

Doras, Willy. 2014. Pengaruh Faktor - faktor Karakteristik Perusahaan terhadap Pergantian Auditor (Studi pada Perusahaan Manufaktur yang listing di BEI Tahun 2010 - 2013). Skripsi Fakultas Ekomomi dan Bisnis Universitas Sultan Ageng Tirtayasa.

Dwiyanti, R. Meika E. dan Sabeni, Arifin. 2014. Faktor-Faktor Yang Mempengaruhi Auditor Switching Secara Voluntary. Diponegoro Journal Of Accounting. ISSN (Online): 23373806. Volume 3, Nomor 3, Tahun 2014.

Faradila, Yuka. dan Yahya, M Rizal. 2016. Pengaruh Opini Audit, Financial Distress, dan Pertumbuhan Perusahaan Klien terhadap Auditor Switching (Studi pada Perusahaan Manufaktur yang Terdaftar di Bursa Efek Indonesia Tahun 2010-2014). Jurnal Ilmiah Mahasiswa Ekonomi Akuntansi (JIMEKA). Vol. 1, No. 1, (2016).

Fitriani, Nurin Ari. Dan Zulaikha. 2014. Analisis Faktor-Faktor Yang Mempengaruhi Voluntary Auditor Switching di Perusahaan Manufaktur Indonesia (Studi Empiris pada Perusahaan Manufaktur yang Terdaftar di Bursa Efek Indonesia (BEI) Tahun 20082012). Diponegoro Journal Of Accounting. ISSN (Online): 2337-3806. Volume 3, Nomor 2, Tahun 2014, Halaman 1-13.

Febrianto, Rahmat. 2009. Pergantian Auditor dan Kantor Akuntan Publik, (http://rfebrianto.com/2009/05/pergantian-auditor-dan-kantor-akuntan.html) diakses 3 Oktober 2018.

Ghozali, Imam. 2016. Aplikasi Analisis Multivariete Dengan Program IBM SPSS 23. Semarang : Badan Penerbit Universitas Diponogoro

Gunady, F., \& Y. Mangoting. 2013. Faktor-Faktor yang Mempengaruhi Keputusan Perusahaan Manufaktur yang Terdaftar di BEI tahun 2008-2012 Melakukan Pergantian KAP. Tax and Accounting Review 3(2). Vol. 3, No.2, 2013.

Hidayati, Wahyu Nurul. 2018. Pengaruh Audit Delay, Reputasi Auditor, Pergantian Manajemen, Financial Distress, Pertumbuhan Perusahaan dan Kepemilikan Publik Terhadap Auditor Switching pada Perusahaan Manufaktur Go Public yang Terdaftar Di Bursa Efek Indonesia (BEI) Periode 2010-2015. Economic, Accounting, Management and Bussines. p-ISSN 2615-3009, e-ISSN 2621-3389. Vol. 1, No. 4, Oktober 2018.

Intitut Akuntan Publik Indonesia. 2011. Panduan Entitas Bisnis Kecil. Jakarta: Salemba Empat. Luthfiyati, Binti. 2016. Pengaruh Ukuran Perusahaan, Opini Audit, Pergantian Manajemen, Ukuran KAP, dan Audit Tenure Terhadap Auditor Switching. Journal Of Accounting.Volume 2 No.2 Maret 2016.

Manto, Juli Is., dan Manda, Dewi Lesmana. 2018. Pengaruh Financial Distress, Pergantian Manajemen, dan Ukuran KAP Terhadap Auditor Switching. Media Riset Akuntansi, Auditing \& Informasi. ISSN 2442-9708 (Online), ISSN 1411-8831 (Print). Vol. 18, No. 2, September $2018: 205-224$.

Muid, Dul., dan Astrini, Retno Novia. 2013. Analisis Faktor-Faktor yang Mempengaruhi Perusahaan Melakukan Auditor Switching Secara Voluntary. Diponogoro Journal of Accounting. ISSN (Online): 23373806. Volume 2, Nomor 3, Tahun 2013.

Nazri, Sharifah. N. F. S. M., Smith, Malcolm., dan Ismail, Zubaidah. 2012. Factor Influencing Auditor Change : Evidence From Malaysia. Asian Review of Accounting. Vol. 20, No. 3, 2012. pp. 222-240.

Pradhana, Made Aditya Bayu., dan Suputra, I.D.G. Dharma. 2015. E-Jurnal Akuntansi Universitas Udayana. ISSN : 2302-8556. Vol. sia11.3 (2015) : 713-729

Priambardi, Raden Bima., dan Haryanto. 2014. Determinan Auditor Switching pada Perusahaan Non Keuangan. Diponogoro Journal of Accounting. ISSN (Online): 2337-3806. Volume 3, Nomor 3, Tahun 2014. 
Priyatna, Gustha., dan Pramono, Hadi. 2015. Pengaruh Financial Distress, Pergantian Manajemen, Pertumbuhan Perusahaan Dan Opini Audit Terhadap Pergantian Auditor pada Perusahaan Manufaktur Yang Terdaftar Di Bursa Efek Indonesia Tahun 20112013. KOMPARTEMEN. Vol. XIII No.2, September 2015.

Putra, I Wayan D W. 2014. Pengaruh Financial Distress, Rentabilitas, Pertumbuhan Perusahaan Dan Opini Audit Pada Pergantian Auditor. E-Jurnal Akuntansi Universitas Udayana. ISSN: 2302-8556 8.2 (2014): 308-323.

Putra, Robby Adytia., dan Trisnawati, Ita. 2016. Faktor yang Mempengaruhi Pergantian Auditor. Jurnal Bisnis, dan Ekonomi. ISSN: 1410-9875. Vol. 18, No. 1, Juni 2016.

Salim, Apriyeni., dan Rahayu, Sri. 2014. Pengaruh Opini Audit, Ukuran KAP, Pergantian Manajemen, dan Financial Distress Terhadap Auditor Switching. e-Proceeding of Management. ISSN : 2355-9357. Vol.1, No.3, Desember 2014.

Sekaran, Uma. 2011. Metodologi Penelitian untuk Bisnis. Jakarta: Salemba Empat

Sianipar, Riduan Febri. 2015. Faktor - Faktor Yang Mempengaruhi Auditor Switching Pada Perusahaan Manufaktur Yang Terdaftar Di BEI (Studi Empiris pada Perusahaan Manufaktur di Bei Tahun 2011-2013). Jom FEKON. Vol. 2 Nomor 2 Oktober 2015.

Soraya, Ella., dan Haridhi, Musfiari. 2017. Faktor-Faktor Yang Mempengaruhi Voluntary Auditor Switching (Studi Empiris pada Perusahaan Non Financing yang Terdaftar di Bursa Efek Indonesia tahun 2011-2015). Jurnal Ilmiah Mahasiswa Ekonomi Akuntansi (JIMEKA). Vol. 2, No. 1 (2017).

Sugiyono. 2013. Metode Penelitian Bisnis. Bandung: Alfabeta

Wea, Alexandros Ngala. S., dan Murdiawati, Dewi. 2015. Faktor-Faktor yang Mempengaruhi Auditor Switching secara Voluntary pada Perusahaan Manufaktur. Jurnal Bisnis dan Ekonomi (JBE). ISSN: 1412-3126.Vol. 22, No., September 2015.

Wijaya, Edwin. dan Rasmini, Ni Ketut. 2015. Pengaruh audit Fee, Opini Going Concern, Financial distress, ukuran perusahaan, ukuran KAP pada pergantian auditor. E-Jurnal Akuntansi Universitas Udayana. ISSN: 2302-8559. Vol. 11.3 (2015). 940-966.

- Peraturan Menteri Keuangan Nomor 17/PMK.01/2008.

- Peraturan Pemerintah Nomor PP No.20 tahun 2015.

s__ - www.idx.co.id 